\title{
Progression and resolution of megalocytic hepatopathy with exocrine pancreatic metaplasia in a population of cultured juvenile striped bass Morone saxatilis
}

\author{
Joseph M. Groff, David E. Hinton, Terry S. McDowell, Ronald P. Hedrick \\ Department of Medicine, School of Veterinary Medicine, University of California, Davis, California 95616, USA
}

\begin{abstract}
An episode of acute mortality that occurred in a population of pond-reared fingerling striped bass Morone saxatilis in northern California, USA, was investigated. Affected fish were darkened and had bilateral exophthalmos and abdominal distension. Livers were enlarged and pale, and a small amount of a serous fluid was present in the pleuroperitoneal cavity. Microscopic examination revealed panhepatic megalocytosis with individual hepatocyte degeneration and necrosis. Electron microscopic examination of hepatocytes revealed invaginations of the nuclear membrane and subsequent herniation of the perinuclear cytoplasm into the nucleus. Mortality among fish moved from the pond to the laboratory declined and then ceased after $8 \mathrm{wk}$, providing an opportunity for serial analysis of repair and resolution. At $12 \mathrm{~d}$ post-submission, proliferation of bile ductular epithelial cells occurred adjacent to foci of degenerative hepatocytes prior to regeneration of morphologically normal hepatocytes. Multifocal areas of exocrine pancreatic metaplasia were also present at $12 \mathrm{~d}$ and persisted until the termination of the study. The etiology of the disease was not determined but standard procedures ruled out a primary microbial infection. Hepatotoxic agents under consideration include pyrrolizidine alkaloids and blue-green algal phytotoxins. These observations indicate that the striped bass is sensitive to potential toxicants but is capable of repair and regeneration following sublethal injury. A pluripotent stem cell capable of differentiation into 3 epithelial cell types may be essential for this repair and regeneration. Experimental exposure studies are in progress to identify the etiological agent and further study the pathogenesis of the hepatic lesions.
\end{abstract}

\section{INTRODUCTION}

An anadromous species that occurs naturally along the Atlantic and Gulf coasts of North America, striped bass Morone saxatilis were introduced into the San Francisco Bay and Sacramento/San Joaquin River Delta (California, USA) from New Jersey (USA) in 1879 and 1881 and became an abundant and valuable fish species (Hardy 1978, Stevens et al. 1985). However, this population has been in decline since the 1960's and is currently at one-third of its former abundance (Stevens et al. 1985). Field investigations suggest that mortality during the larval stage is substantial and may be currently greater than it was in past years (Eldridge et al. 1981). Several factors may be associated with larval mortality including: entrainment in water diversions, starvation induced by an overall decline in larval food abundance, predation by other organisms or toxic sub- stances in the water, sediment or food chain of the San Francisco Bay and Sacramento/San Joaquin River Delta. An annual die-off of mature striped bass observed at Carquinez Strait has focused additional attention on toxic insults (Brown et al. 1987).

In an effort to maintain the population, the California Department of Fish and Game has established a mitigation program to stock several million hatcheryreared fingerlings each year. Participant commercial aquaculturists capture and transport feral broodstock to hatcheries where eggs are fertilized and the resultant embryos are cultured. Posthatch larvae are placed in 20 acre (ca 8 ha) earthen ponds for further growth. Water in ponds is enriched for algae, and larvae are allowed to feed and grow until they are released as fingerlings.

An investigation was initiated at one facility to determine the cause of an acute mortality in fingerling striped bass in one pond. Although the etiologic 
agent(s) was/were not determined, the initial liver alterations and their resolution afforded a rare opportunity to examine hepatic injury and recovery in this important sport fish. These findings are of importance in establishing histopathologic biomarkers of exposure and effect in striped bass. The present report describes a condition of suspected toxicopathic hepatic megalocytosis and necrosis with intranuclear pseudoinclusion formation and subsequent exocrine pancreatic metaplasia.

\section{CASE HISTORY}

The initial sample of fingerling striped bass $(\mathrm{n}=16)$ were ca 2 to 3 mo of age with a mean weight of $0.5 \mathrm{~g}$ and mean length of 5 to $6 \mathrm{~cm}$. They were progeny of captive broodstock maintained at a private culture facility in northern California. The fish were cultured at a density of 370000 larvae $\mathrm{ha}^{-1}$ in shallow earthen ponds supplied by well water and fertilized with cow manure prior to use. The eutrophic ponds had abundant algal blooms and clippings of terrestrial vegetation bordering the ponds were discarded into the ponds $6 \mathrm{wk}$ prior to the episode of increased mortality. The mortality approached $100 \%$ and was restricted to 1 pond. Fish in separate ponds on the same property were not affected.

\section{MATERIALS AND METHODS}

Fifty additional fish from the affected population were obtained $12 \mathrm{~d}$ after the initial submission and were maintained at the University of California, Davis (UC Davis) in 51 aquaria supplied with non-recirculating well water at $22^{\circ} \mathrm{C}$ with a flow rate of $0.5 \mathrm{l} \mathrm{min}{ }^{-1}$. They were fed a commercial, dry, pelleted feed (Silvercup, Nelson and Sons, Murray, UT, USA) and were examined daily for morbidity and mortality. Moribund fish were sampled at 27 and $50 \mathrm{~d}$ and survivor fish were sampled at 165 and $300 \mathrm{~d}$.

Microbiology. Moribund fish from the initial submission were euthanized with $500 \mathrm{mg} \mathrm{l}^{-1}$ of tricaine methanesulfonate (MS-222). Fresh gill and integument scrapings were mounted on glass slides and examined for external pathogens. Kidney, spleen and liver were cultured after aseptic exposure of the pleuroperitoneal cavity and inoculated on blood and brain-heart infusion (BHI) agar Bacterial cultures were incubated at $22^{\circ} \mathrm{C}$ and examined daily for growth.

Two 5-fish pools of viscera from the original submission were extracted and inoculated at 1:50 on CHSE214, EPC and BF-2 cell lines using standard procedures (Amos 1985). After $12 \mathrm{~d}$ of incubation at $15^{\circ} \mathrm{C}, 0.1 \mathrm{ml}$ of the medium from each culture was removed, diluted
1:50 and used to inoculate a new monolayer of cells (blind-passage). Liver samples from fish obtained $12 \mathrm{~d}$ after the initial submission were also extracted and inoculated on the same 3 established cell lines and primary striped bass gonadal and hepatic cell cultures, incubated at $15^{\circ} \mathrm{C}$ and passed after $12 \mathrm{~d}$ as described above.

Light microscopy. Whole fish with exposed pleuroperitoneal cavities were placed in Bouin's fixative for $48 \mathrm{~h}$ and then transferred to $70 \%$ ethanol prior to standard paraffin embedding and sectioning (Humason 1979). Liver samples from additional fish were also processed after fixation in Davidson's solution (Humason 1979) for $24 \mathrm{~h}$. Tissue sections were cut to $6 \mu \mathrm{m}$ and stained with Harris' hematoxylin and eosin, periodic acid-Schiff (PAS) and Feulgen reagents (Luna 1968). Fish histologic processing methods have previously been described (Hinton 1990). Age-matched normal striped bass from the UC Davis Aquaculture and Fishery Program's Aquatic Center were used as a reference.

Electron microscopy. The liver was cut into $1 \mathrm{~mm}^{3}$ sections and then fixed in $2.5 \%$ glutaraldehyde in

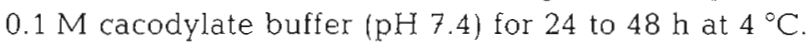
Liver sections were then rinsed twice in buffer and post-fixed in $1 \%$ aqueous osmium tetroxide, dehydrated through a graded ethanol series, infiltrated and embedded in Spurr's low viscosity medium. Thin sections $(10$ to $20 \mathrm{~nm})$ were stained with uranyl acetate and lead citrate prior to examination with a Phillips EM 400 electron microscope at $75 \mathrm{kV}$. Livers from feral $38 \mathrm{~mm}$ larvae were used as an ultrastructural reference.

\section{RESULTS}

\section{Gross examination}

Moribund fish were lethargic and emaciated with loss of normal pigmentation over the posterior half of the body. Affected fish also had abdominal distension and bilateral exophthalmos. The livers were enlarged and a pale tannish-brown. The pleuroperitoneal cavities contained a small amount $(<1.0 \mathrm{ml})$ of a clear, serous fluid

\section{Microbiology}

Wet mount examination of gills and integument scrapings of moribund fish from the initial submission revealed a moderate to severe external infection with Ambiphyra spp., Icthyobodo spp. and Flexibacter columnaris. However, aseptic cultures of kidney, spleen and liver were negative for bacterial growth after $14 \mathrm{~d}$ Cell lines inoculated with extracted viscera or livers 
were also negative for cytopathic effect in original and blind-passaged cultures after $22 \mathrm{~d}$ total incubation.

\section{Light microscopy}

Reference striped bass had normal tissue morphology as compared to published descriptions (Groman 1982). Occurrence and progression of hepatic lesions are summarized in Table 1 . The most significant findings in the moribund fish from the initial submission involved the livers. Normal hepatic parenchyma was either absent or dispersed without apparent pattern. The hepatic sinusoids and the normal tubular to ellipsoidal structure of hepatic glands, i.e. tubules (Hampton et al. 1988), were obscured due to a focally diffuse to panhepatic megalocytosis (Fig, 1A, B, C). Megalocytosis often accentuated the tubular structure of the hepatic glands observed in transverse section. Severity of lesions varied throughout the hepatic parenchyma. Megalocytic hepatocytes measured up to $36 \times 40 \mu \mathrm{m}$ and either had a fine, fibrillar, eosinophilic to amphophilic cytoplasm (Fig. 1B) or contained multiple, variably sized, nondiscrete, PAS-negative, cytoplasmic vacuoles that were often coalescent (Fig. 1E). The smooth, rounded margins of these vacuoles were suggestive of lipid. Hepatocytes also contained hyalinized, eosinophilic, cytoplasmic inclusions that were PAS-positive and delineated by a thin, incomplete, irregular membrane (Fig. 1F).

Megalocytic hepatocytes also had prominent karyomegaly and nuclear pleomorphism (Fig. 1B, C). The enlarged, pleomorphic nuclei measured up to 30 $\times 32 \mu \mathrm{m}$. Nuclei were generally hypochromatic with clumped chromatin and contained one to several prominent nucleoli. Nuclei also contained one to several membrane-bound intranuclear inclusions of variable size and shape although the inclusions were generally oval and had a maximum size of $25 \mu \mathrm{m}$ (Fig. 1B, C). A flocculent, eosinophilic to basophilic material that was often slightly PAS-positive but Feulgen-negative occupied the inclusions. A hyalinized eosinophilic or deeply basophilic material occurred within other inclusions. Occasional inclusions were vacuolated or partitioned by septa and multiple, coalescent inclusions were also observed. The nuclear envelopes were often continuous with the membranes of the inclusion bodies (Fig. 1C).

Megalocytic hepatocytes were often multinucleated and resembled syncytial cells, perhaps due to hepatocellular fusion and loss of plasmalemma (Fig. 1D). Necrosis of individual megalocytic hepatocytes resulted in parenchymal cystic spaces (Fig. 1E). An increased number of inflammatory cells characterized as lymphocytes, monocytes and macrophages occurred within the hepatic vasculature and sinusoids with vascular margination and migration into the hepatic parenchyma. Inflammatory cells infiltrated the hepatic glands and were applied to the plasmalemma of degenerative hepatocytes. The cystic parenchymal spaces were often completely occupied by mononuclear inflammatory cells. Infiltration of inflammatory cells occurred in focally diffuse zones of glandular loss and diffusely throughout the liver (Fig. 1D).

Moribund fish from the initial submission also had mild to moderate gill epithelial hyperplasia, mild renal

Table 1 Morone saxatilis. Occurrence and progression of hepatic lesions in a population of cultured juvenile striped bass associated with mortality that approached $100 \%$ during an 8 wk period. 0 d: date of initial submission; n: number of fish examined; severity of the lesion: $(-)=$ absent $+=$ mild $_{i}++=$ moderate $+++=$ severe $_{\text {; }}$ occ. $=$ occasional

\begin{tabular}{|c|c|c|c|c|c|c|}
\hline Lesion & $\begin{array}{c}0 \mathrm{~d} \\
(\mathrm{n}=11)\end{array}$ & $\begin{array}{c}12 \mathrm{~d} \\
(\mathrm{n}=15)\end{array}$ & $\begin{array}{c}27 d \\
(n=3)\end{array}$ & $\begin{array}{c}50 \mathrm{~d} \\
(\mathrm{n}=6)\end{array}$ & $\begin{array}{c}165 \mathrm{~d} \\
(\mathrm{n}=10)\end{array}$ & $\begin{array}{c}300 \mathrm{~d} \\
(\mathrm{n}=5)\end{array}$ \\
\hline Cellular swelling & +++ & +++ & ++ & ++ & $(-)$ & $(-)$ \\
\hline Megalocytosis & ++ & +++ & +++ & ++ & occ. & occ. \\
\hline Vacuolar hepatopathy & +++ & +++ & +++ & ++ & $(-)$ & $(-)$ \\
\hline Eosinophilic intracytoplasmic inclusions & + & ++ & +++ & +++ & $(-)$ & $(-)$ \\
\hline Karyomegaly & $++t$ & +++ & $+t+$ & +++ & + & \\
\hline Nuclear pleomorphism & +++ & +++ & +++ & +++ & occ. & occ. \\
\hline Intranuclear inclusions & +++ & +++ & +++ & +++ & occ. & occ. \\
\hline Nuclear cytoplasmic invagination & ++ & ++ & ++ & ++ & $(-)$ & $(-)$ \\
\hline Hepatocellular fusion & +++ & +++ & ++ & + & $(-)$ & $(-)$ \\
\hline Hepatic necrosis & + & ++ & ++ & ++ & $(-)$ & $(-)$ \\
\hline Fibroplasia & $(-)$ & + & ++ & ++ & $(-)$ & $(-)$ \\
\hline Inflammatory cell infiltration & ++ & +++ & +++ & ++ & $(-)$ & $(-)$ \\
\hline Hepatic regeneration & $(-)$ & ++ & ++ & $t+t$ & +++ & +++ \\
\hline Oval cell proliferation & $(-)$ & +++ & +++ & ++ & $(-)$ & $(-)$ \\
\hline Pancreatic metaplasia & $(-)$ & ++ & +++ & +++ & +++ & +++ \\
\hline Bile duct hyperplasia & $(-)$ & + & ++ & ++ & $(-)$ & $(-)$ \\
\hline
\end{tabular}



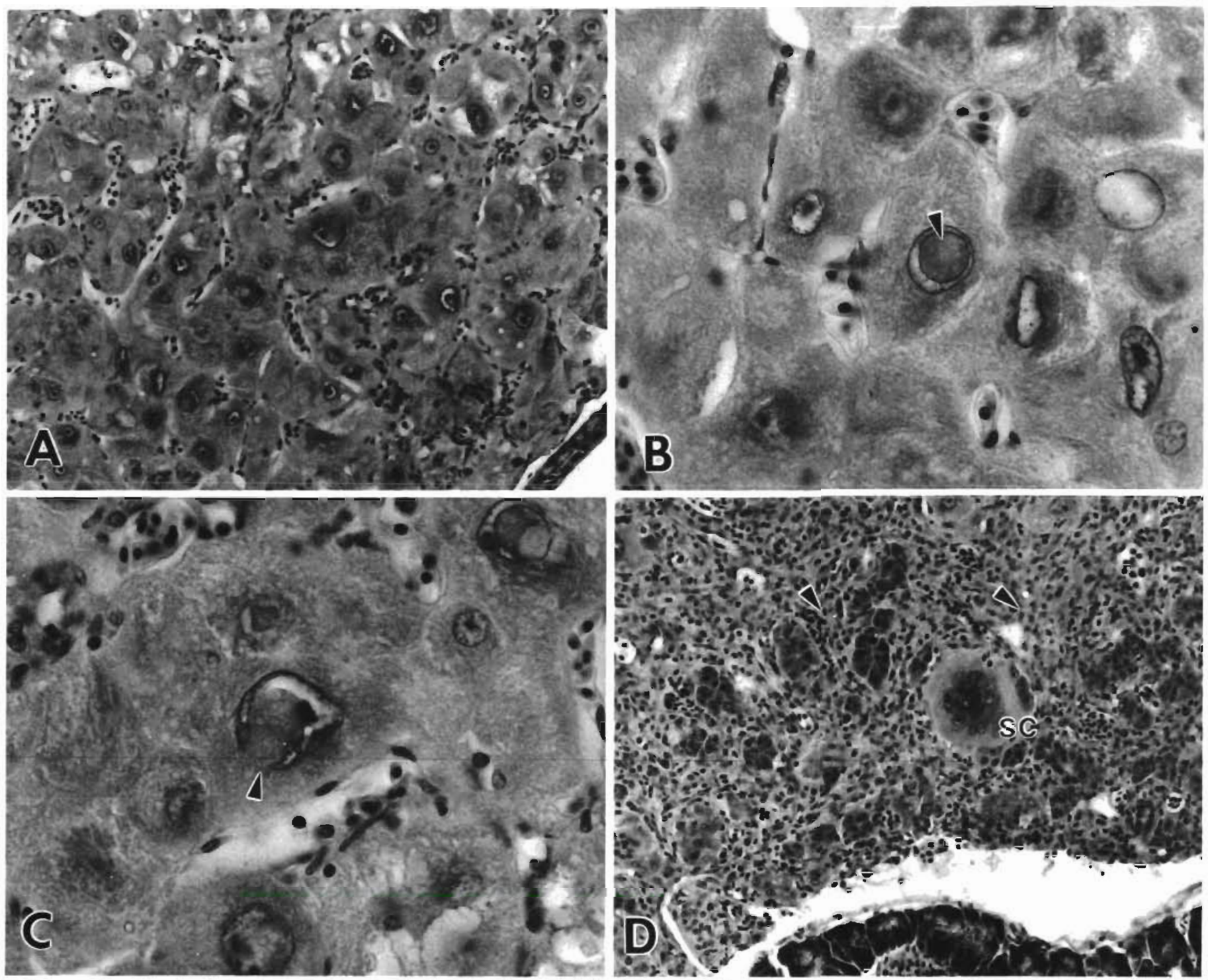

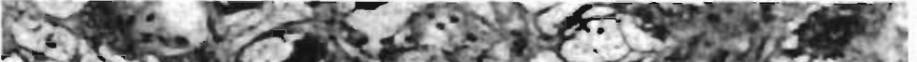

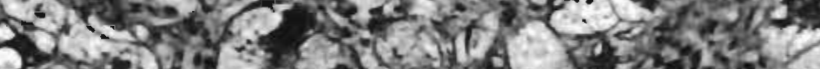

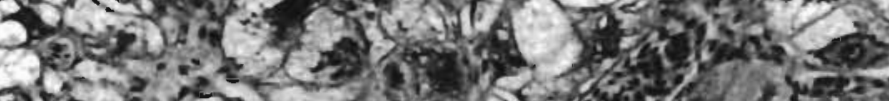
D. 3.

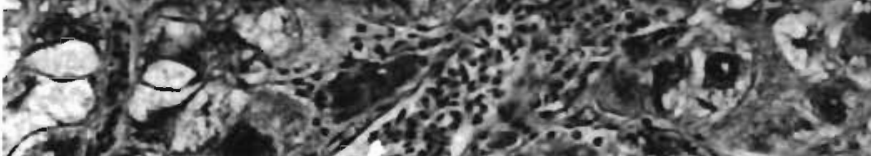
(3.) Nu

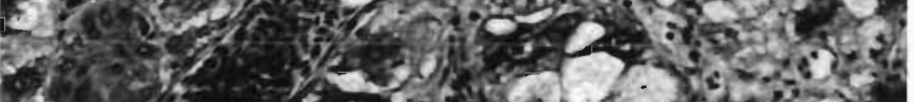
(1) 10.2014

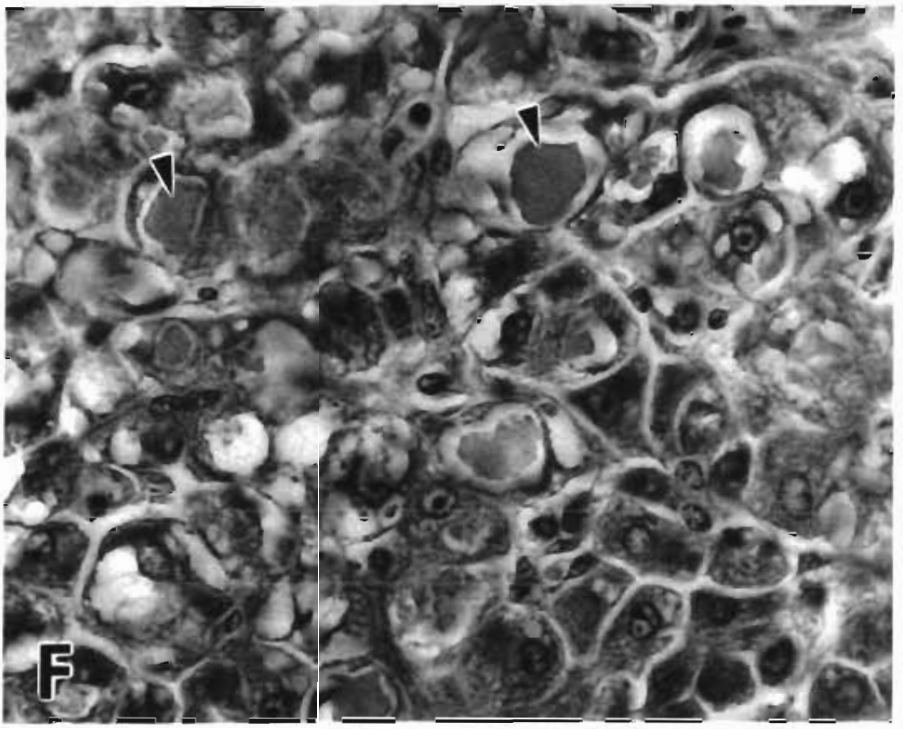


tubular epithelial cell vacuolation with mild, random tubular necrosis and an apparent circulatory leukocytosis. A few fish had a chronic, moderate atrial epicarditis with hyperplasia of the reticuloendothelial cells lining the sinuses of the heart. There was also a mild to moderate, subacute peritonitis and extrahepatic pancreatitis. The zymogen granules of both the extrahepatic and intrahepatic exocrine pancreatic cells were coarse and clumped with loss of the normal eosinophilic tinctorial quality.

Fish examined 12 and 50 d after the initial submission had similar hepatic lesions although there were multiple foci of hepatic regeneration (Fig. 2A). Regenerative cells resembled hepatocytes. Although some ductular biliary forms were seen, regenerative cells were often arranged in sheets rather than the normal tubular pattern. Nuclei of the regenerative hepatocytes were often eccentrically placed and the cytoplasm often contained single, large, discrete, PASnegative, oval, smooth-walled vacuoles suggestive of lipid inclusions. Hyalinized, eosinophilic, PAS-positive cytoplasmic inclusions were especially prominent in these fish. Nests composed of several spherical to oval cells (Fig. 2B) often occurred in a centrotubular position within the hepatic glands or occasionally in an apparent intertubular location. These cells had an average size of $5 \times 7 \mu \mathrm{m}(\mathrm{n}=20)$ and contained a scant amount of a pale, eosinophilic to amphophilic cytoplasm.

Similar nests of cells were also present within the cystic parenchymal spaces. These cells, however, were variable in size with a polygonal profile (Fig. 2C) and often occurred adjacent to the preexisting, perivascular, intrahepatic exocrine pancreatic tissue. They were further characterized by a prominent basophilia of the cytoplasm and small, oval, eccentric nuclei. Progressive maturation and enlargement of these cells resulted in an arrangement and appearance of cells that resembled normal exocrine pancreatic tissue with a normal complement of multiple, deeply eosinophilic, zymogen granules (Fig. 2D). The pancreatic metaplasia was initially located adjacent to the preexisting, intrahepatic pancreatic tissue with progressive extension into the hepatic parenchyma and proliferation within the parenchymal cystic spaces although occasional metaplastic foci were observed throughout the liver. Mild bile duct proliferation and inflammation with multifocal areas of fibroplasia were also observed in these fish.
Hepatic regeneration with restoration of the normal hepatic architecture was complete in fish sampled at $165 \mathrm{~d}$ (Fig. 2E) although occasional hepatocytes often had discrete, oval, membrane-bound, clear, intranuclear inclusions or inclusions that contained a scant amount of a flocculent material (Fig. 2F). Occasional megalocytic hepatocytes were also observed. Pancreatic metaplasia occurred in all fish (Fig. 2E) and was often focally extensive. In 1 fish approximately $40 \%$ of the liver section was occupied by acini of exocrine pancreas. These changes persisted until the study was terminated at $300 \mathrm{~d}$.

\section{Electron microscopy}

Livers from feral $38 \mathrm{~mm}$ larvae used as an ultrastructural reference did not differ appreciably from observations in other species (Hinton \& Pool 1976, Hampton et al. 1985, Laurén et al. 1990). Electron microscopic examination of the affected striped bass confirmed and extended the light microscopic observations. The hepatocyte nuclear membrane had numerous creases and invaginations (Fig. 3). In longitudinal orientation, elements of the perinuclear cytoplasm were contained within the nucleus and the nuclear membrane that delineated the cytoplasm also had invaginations consistent with an interpretation of pseudoinclusions (Fig. 3). Pseudoinclusions were prominent in livers of fish from the initial sample and fish sampled at 12 and $50 \mathrm{~d}$. Pseudoinclusions contained abundant profiles of swollen endoplasmic reticulum and mitochondria with dispersion of the cytosol (Fig. 3). Nucleoli were widely separated and some nuclei showed 3 or more nucleoli. Segregation of the pars fibrosa and granulosa was also apparent (Fig. 3). Proliferation of the endoplasmic reticulum was a prominent feature of some hepatocytes (Fig. 3). Normally, 5 to 7 parallel stacks of lamellae form a perinuclear cuff and a similar number of lamellae occur at the cell periphery (Hinton \& Pool 1976). Individual lamellae in these fish, however, were shorter than normal (Fig. 4). Numerous vesicles of endoplasmic reticulum occurred at the edges of the parallel stacks. Higher magnification (Figs. 4 \& 5) revealed cisternal spaces that were enlarged and electron-lucent or nearly filled with electron-dense particles typical of lipid. Intracisternal lipid particles ranged from 35 to

Fig. 1. Morone saxatilis. Spectrum of hepatic lesions in cultured juvenile striped bass associated with mortalities that approached $100 \%$ during an 8 wk period. Hematoxylin and eosin. (A) Panhepatic megalocytosis, $\times 178$. (B) Megalocytic hepatocytes with karyomegaiy and intranuclear inclusions (arrow), $\times 256$. (C) Megalocytic hepatocyte with nuclear invagination of the cytosol (arrow), $\times 256$. (D) Multinucleated syncytial cell (sc) and severe mononuclear inflammatory cell infiltration (arrows), $\times 178$. (E) Vacuolar hepatopathy with hepatocyte degeneration and necrosis, $\times 178$. (F) Eosinophilic, hyalinized, intracytoplasmic inclusions (arrows), $\times 178$ 

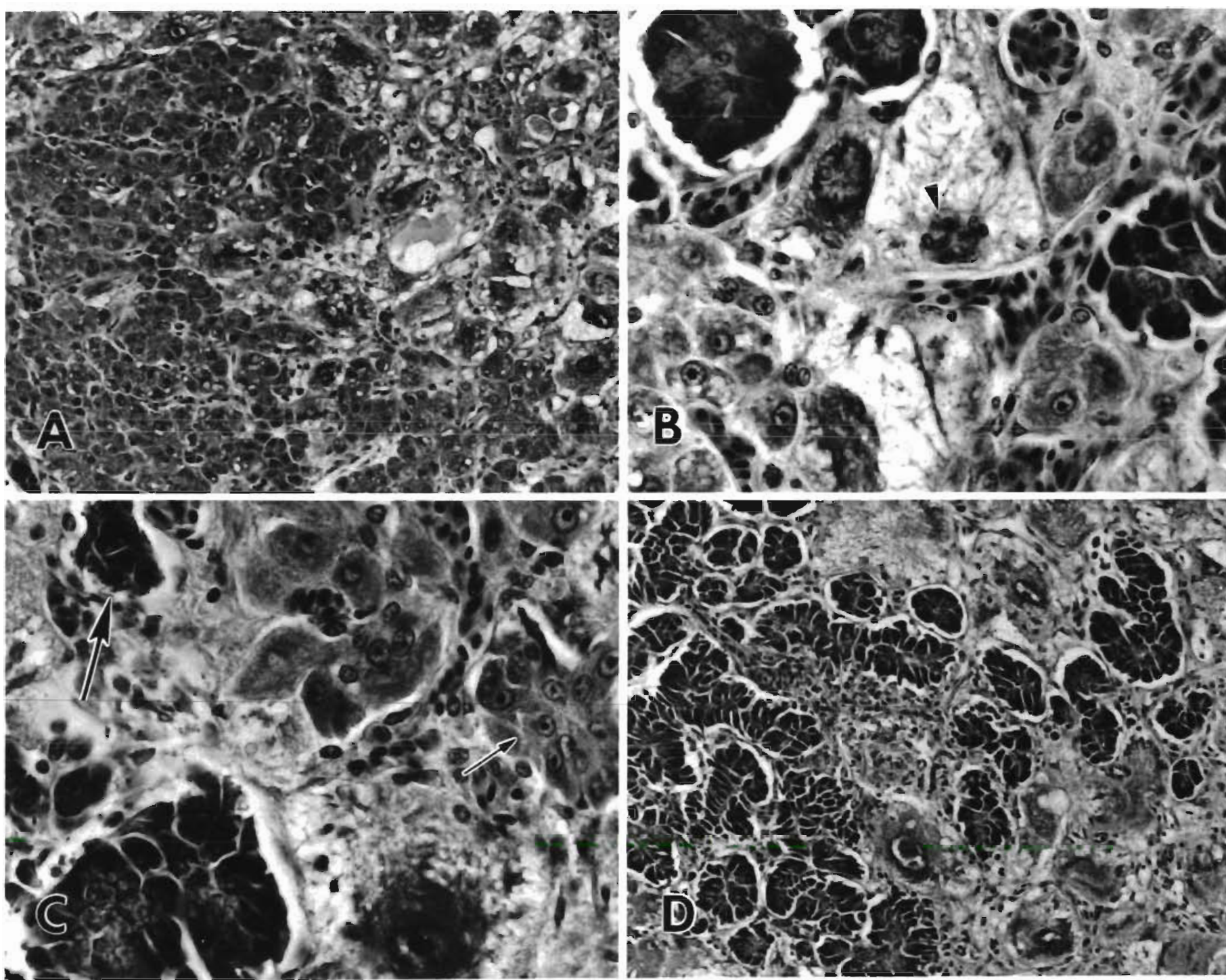
1...

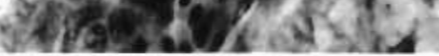

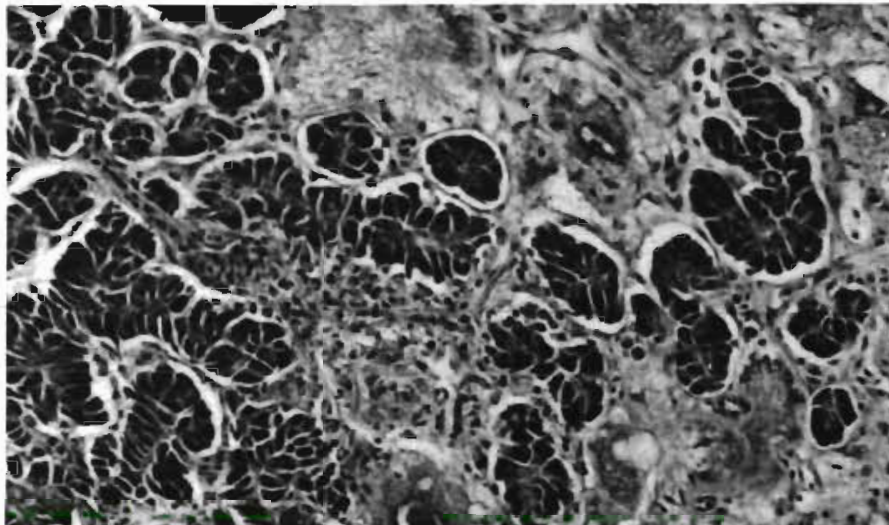

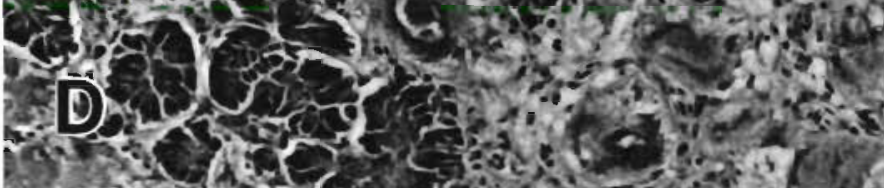

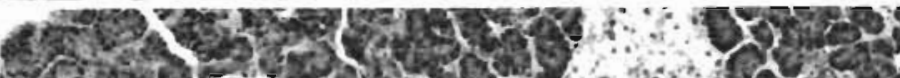

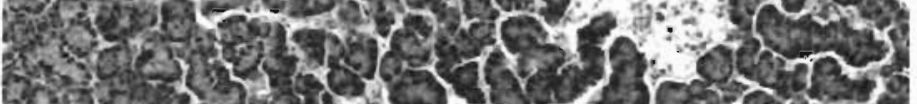

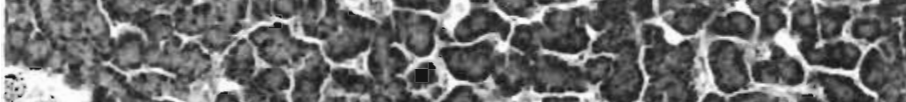

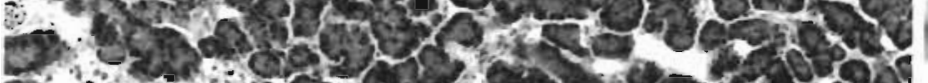

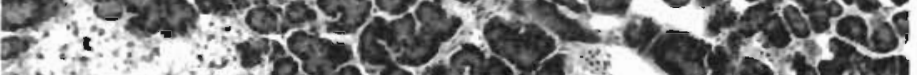

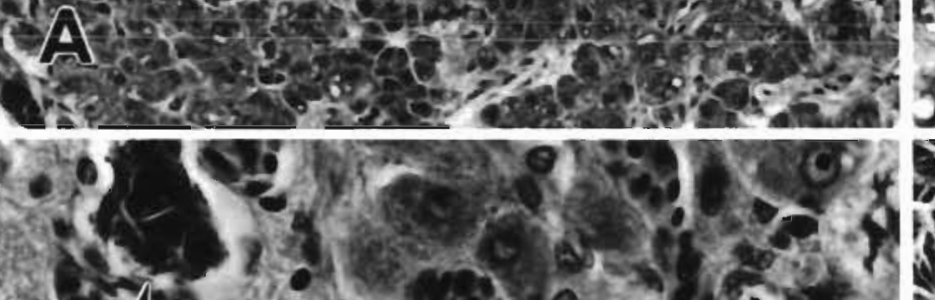
$\cdots$. 3 .

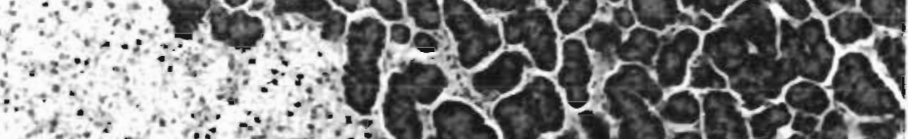

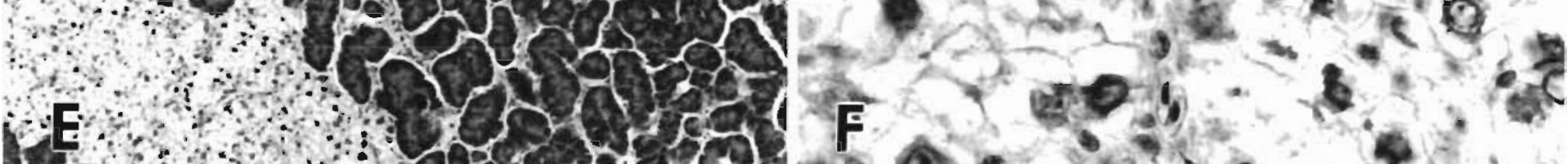
ge 
$93 \mathrm{~nm}$ in diameter and were consistent with transport lipoprotein (Fig. 5). Cytosolic lipid vacuoles were oval with an average diameter of $93 \mathrm{~nm}(n=20)$ (Fig. 5). An increased amount of lipoprotein particles that were apparently being extruded from hepatocytes were occasionally observed at the basal (sinusoidal) plasma membrane (Fig. 5). Golgi-derived condensing vesicles with abundant lipoprotein particles were also common (Fig. 5). The peripheral hepatocyte cytoplasm also contained numerous coated vesicles. Hepatocyte glycogen was depleted in the livers of fish from the initial samples and the early recovery phases at 12 and $50 \mathrm{~d}$. Also, the mitochondria were consistently swollen (Fig. 4). Peroxisomes (Fig. 4) did not appear affected.

Biliary epithelial cells were observed in regenerative islands. Single elongated cells or nests composed of several similar cells were located at the apical-lateral borders of adjacent hepatocytes between the canaliculi and bile ductules in a centrotubular position and were joined to hepatocytes by intercellular junctions (Fig. 6). Biliary epithelial cell nuclei were not altered (Fig. 6). Heterochromatin was condensed but finely dispersed throughout the nucleoplasm and the nuclei had a prominent, eccentric nucleolus. Biliary epithelial cells were further characterized by a scant amount of cytoplasm that contained polyribosomes and free polysomes, oval to spherical mitochondria, intermediate filaments $(10 \mathrm{~nm})$, microtubules and vesicles. Numerous autophagic vacuoles, lysosomes and residual bodies suggested an alteration of biliary epithelial cells (Fig. 6). The cells had meandering and often interdigitating lateral borders and were joined to adjacent biliary epithelial cells by numerous desmosomes (Fig. 6).

Viral particles or other microbial pathogens were not observed.

\section{DISCUSSION}

The primary cause of mortality was not determined. Although it was most likely due to severe hepatocellular toxicity in combination with moderate to severe external parasitic and bacterial infection, subsequent efforts to obtain water, algal cultures and plant clippings from the producer were unsuccessful, as the pond with the disease outbreak had been drained. Morphology of the hepatic lesions and the unsuccessful attempts to isolate or observe internal pathogens using standard diagnostic procedures support this hypothesis

Aspects of this outbreak and its follow-up investigation are important concerning toxicologic pathology of fishes. First, hepatic lesions were cell specific (hepatocyte megalocytosis with nuclear pseudoinclusions; biliary epithelial cell-hyperplasia of regeneration; exocrine pancreatic cell-metaplasia). Second, duration of liver injury and chronicity of host reaction were established. The majority of aquatic toxicity bioassays are designed to assess acute or subacute toxicity. Histopathologic examination usually is employed at the termination of chronic bioassay (Meyers \& Hendricks 1985). This has led to a paucity of data on duration of specific lesion(s) and time required for their repair. Third, the lesions observed have been included among 'present histopathologic biomarkers' recommended for use in field studies determining whether feral fish have been exposed and adversely affected by xenobiotics (Hinton et al. 1992). Subcellular alterations in our study were manifested grossly as hepatomegaly and microscopically as hepatocellular hypertrophy with vacuolation, referred to as hydropic degeneration or cellular swelling (Cotrans et al. 1989). The swollen endoplasmic reticulum and mitochondria with dispersion of cytosol and nuclear chromatin, a nonspecific finding reportedly associated with sublethal, reversible cellular injury including toxic insult (Popper 1988, Cotrans et al. 1989), were considered a sequel to structural or functional defects with consequent loss of osmoregulatory capability. The marked swelling of the endoplasmic reticulum and mitochondria within vacuolated cells resembled a condition previously reported in winter flounder Pseudopleuronectes americanus from Boston Harbor (Bodammer \& Murchelano 1990). Hepatocellular vacuolation in winter flounder (Murchelano \& Wolke 1985, Gardner et al. 1989, Moore et al. 1989, Bodammer \& Murchelano 1990) and windowpane flounder Scophthalmus aquosus (Murchelano \& Wolke 1985) has been regarded as a variant of hydropic degeneration. In advanced age classes of winter flounder from Boston Harbor and nearby estuaries, hepatocellular vacuolation has been highly correlated with cholangiocytic, and, to a lesser degree, hepatocellular neoplasms but is also seen in fish without evidence of neoplasia (Harshbarger \& Clark 1990). There was no evidence of hepatic neoplasia in these striped bass although the oldest fish examined was only 1 yr old.

Fig. 2. Morone saxatilis. Hepatic regeneration in striped bass maintained in captivity from a population with megalocytic hepatopathy and an associated increased mortality. Hematoxylin and eosin. (A) Focus of hepatic regeneration $12 \mathrm{~d}$ after initial submission, $\times 178$. (B) Nest (arrow) composed of several spherical to oval cells within an hepatic gland at $12 \mathrm{~d}, \times 256$. (C) Focus of immature pancreatic metaplasia (large arrow) and bile duct hyperplasia (small arrow) at $12 \mathrm{~d}, \times 256$. (D) Local extension of pancreatic metaplasia at $27 \mathrm{~d}, \times 178$. (E) Restoration of normal hepatic architecture with extensive pancreatic metaplasia at $165 \mathrm{~d}$, $\times 89$. (F) Normal hepatic architecture at $300 \mathrm{~d}$ with occasional megalocytic hepatocytes with intranuclear inclusions. (arrow), $\times 178$ 


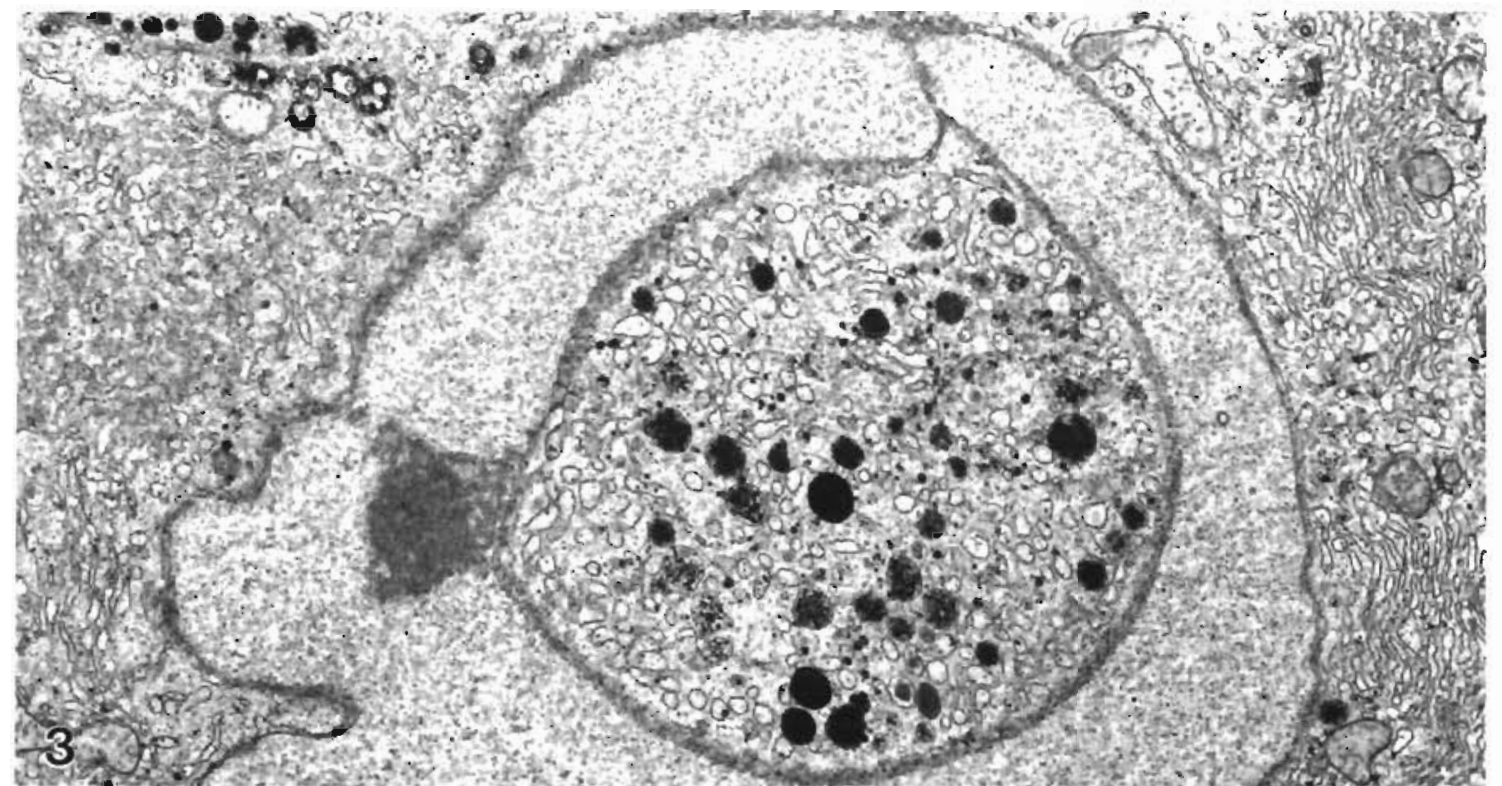

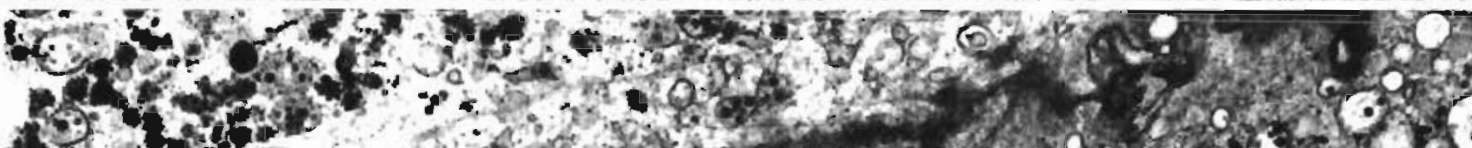

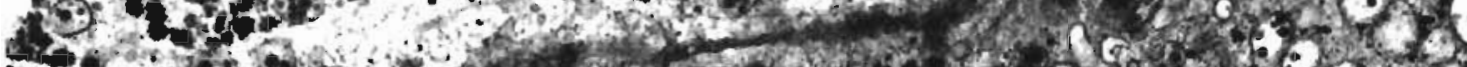
5. -2.

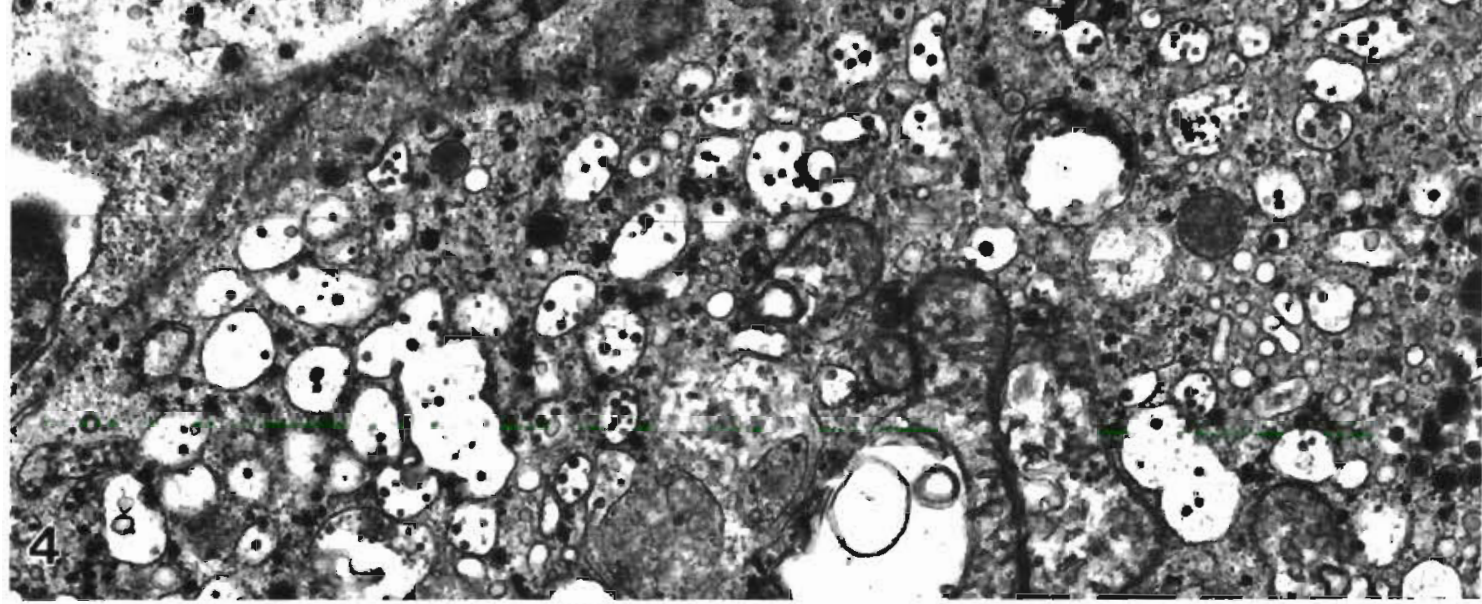
7. 0 . Tro

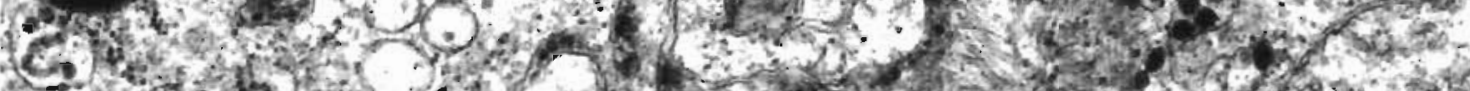

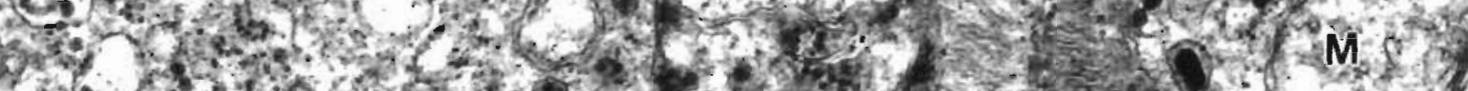

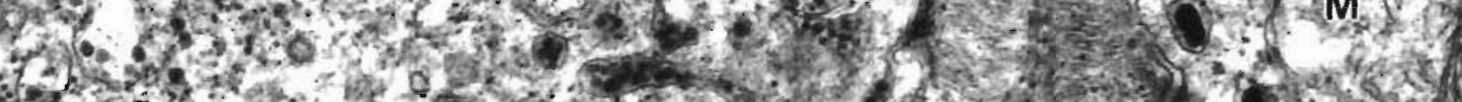

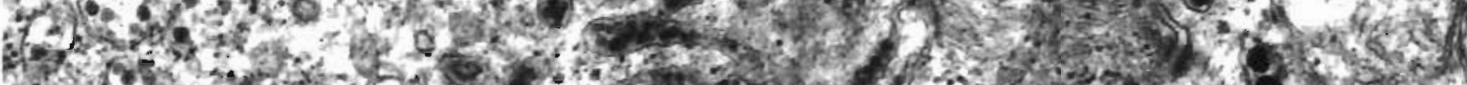

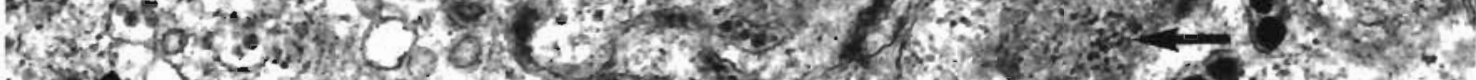

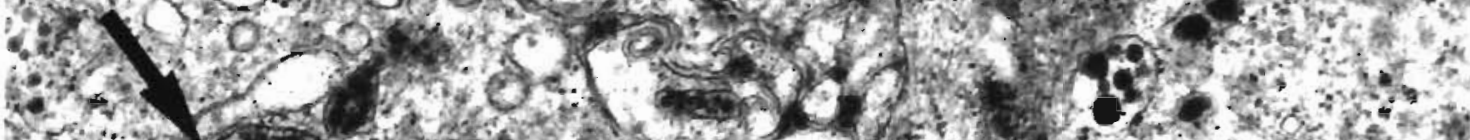

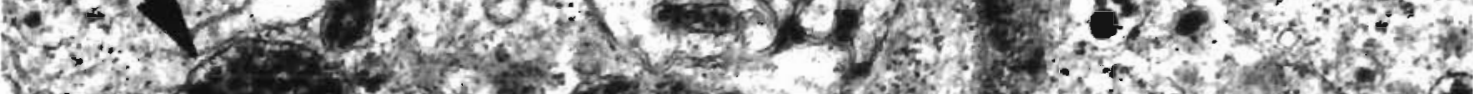

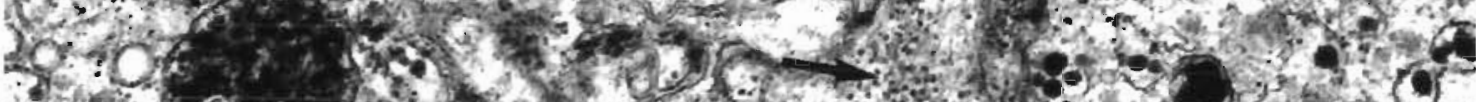

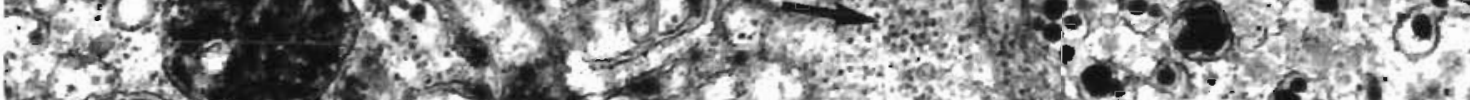

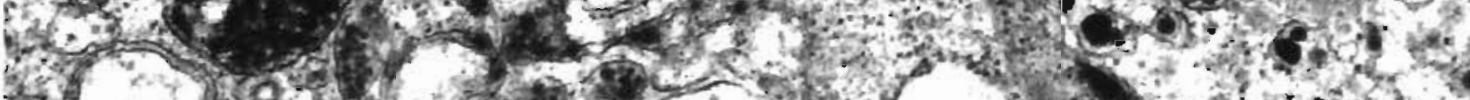

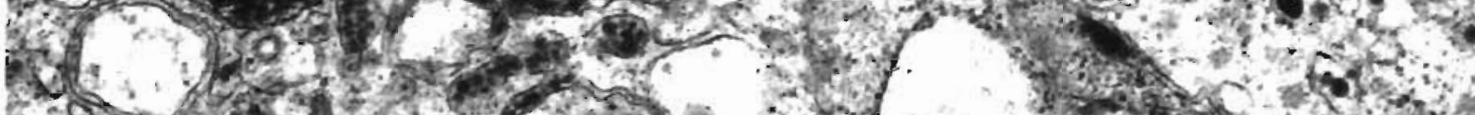

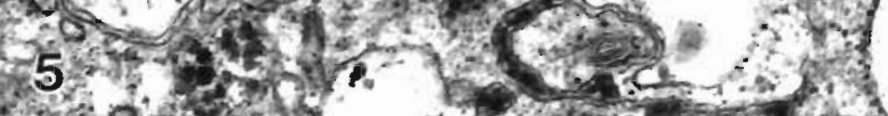

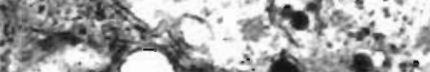
- 2 .

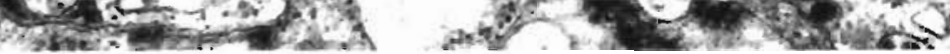


Fig. 6. Morone saxatilis. Bile ductular epithelial cells show numerous desmosomes and electron-lucent cytoplasm. Thin portion of adjacent hepatocyte is at top of field. Uranyl acetate and lead citrate, $\times 18630$

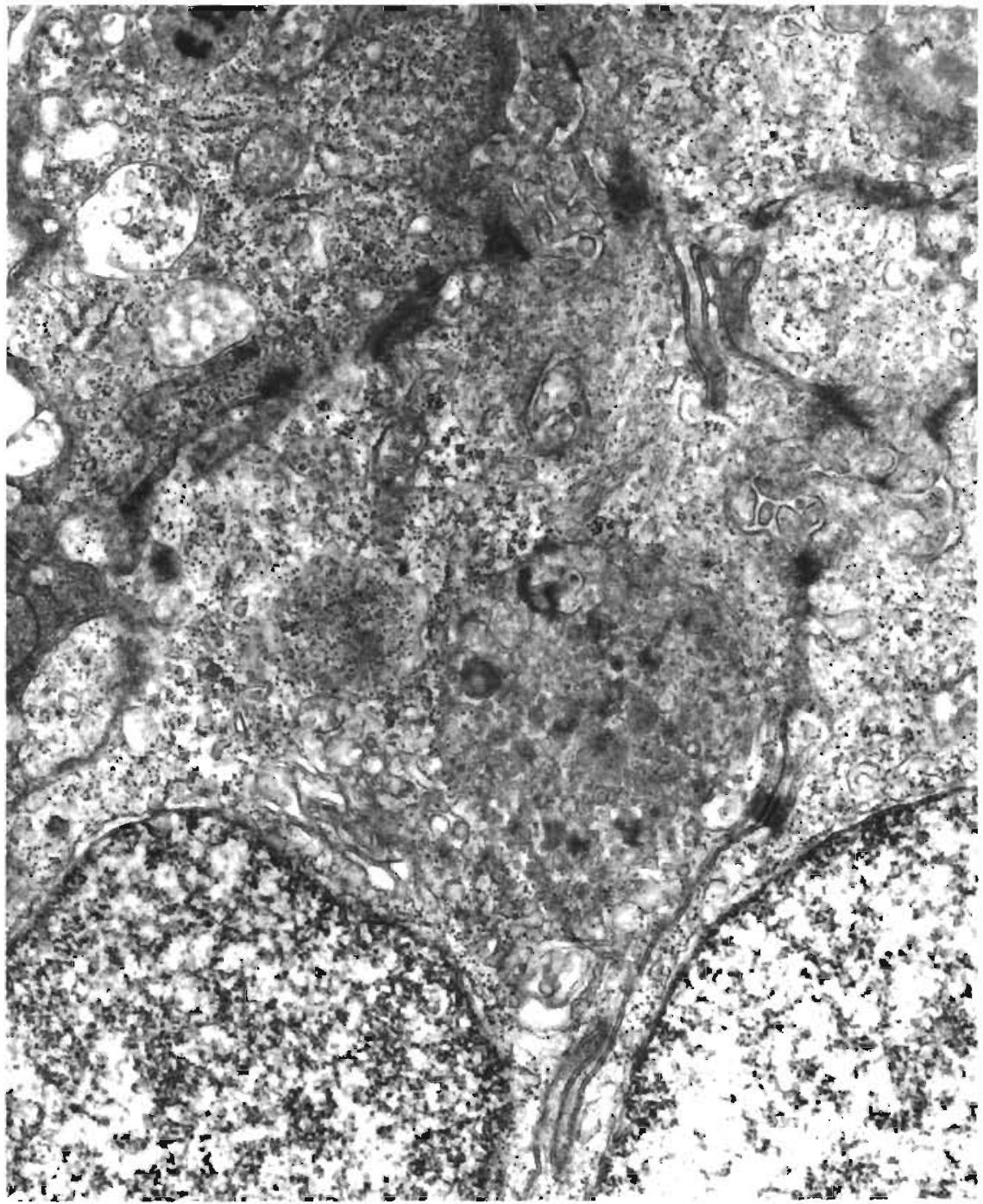

An apparent proliferation of hepatocyte endoplasmic reticulum (Figs. 3 \& 4) was composed of individual lamellae that were shorter than normal. Numerous vesicles of endoplasmic reticulum, also found at edges of parallel stacks, suggested that vesiculation may have accounted for the shortened individual lamellae. Proliferation of endoplasmic reticulum was also shown to occur in mullet Mugil cephalus exposed to the polynuclear aromatic hydrocarbon, 3-methylcholanthrene (Schoor \& Couch 1979), and in the channel catfish
Ictalurus punctatus after subacute exposure to Aroclor 1254 (Klaunig et al. 1979). Braunbeck et al. (in press) has reported that normal sexually mature female fish of various species exhibit abundant endoplasmic reticulum during hepatocyte previtellogenin production although the sexual immaturity of these striped bass suggested that the changes were not due to seasonal variations.

Lipid accumulation, as cytosolic vacuoles and intracisternal transport lipid, suggested either exces-

Figs. 3 to 5. Morone sexatilis. Fig. 3. Transmission electron micrograph of hepatocyte from affected striped bass. Nuclear margin is irregular in appearance and shows invagination resulting in a pseudoinclusion. Endoplasmic reticulum has apparently proliferated with abundant stacks clustered near nucleus and extending toward periphery of cell. Some m:tochondria are swollen. Uranyl acetate and lead citrate, $\times 7560$. Fig. 4. Portions of 2 hepatocytes are shown. Endoplasmic reticulum is vesiculated and cisternae appear swollen and contain numerous, small lipid particles. Mitochondria are swollen while peroxisomes appear normal. Uranyl acetate and lead citrate, $\times 16200$ Fig. 5 . Peripheral portions of 2 hepatocytes are shown. Lipid particles in ER cisternae vary from 35 to $93 \mathrm{~nm}$ in diameter Other sites for lipid particles are within Golgi-derived condensing vesicles (large arrow) and within intercellular space at cell border (small arrows). Mitochondria (M) are swollen. Uranyl acetate and lead citrate, $\times 31050$ 
sive lipid transport, or partial blockade of the intracellular lipoprotein transport system with a consequent accumulation of lipid. Accumulations of lipoprotein particles at the basal (sinusoidal) plasma membrane and Golgi-derived condensing vesicles containing abundant lipoprotein particles further suggested a lipoprotein particle retention. Excessive lipid transport and accumulation was also a nonspecific cellular change similarly associated with sublethal, reversible cellular injury including toxic insult and was considered a sequela to alterations in the normal hepatocyte metabolism of triglycerides and secretion of lipoprotein (Plaa 1986, Cotrans et al. 1989). This condition has also been reported in medaka Oryzias latipes after exposure to diethylnitrosamine (Laurén et al. 1990, Braunbeck et al. in press).

Although cellular swelling, lipid accumulation and megalocytosis are examples of reversible cellular injury, necrosis of individual megalocytic hepatocytes and entire hepatic glands in the livers of fish from the initial submission and fish sampled at 12 and $50 \mathrm{~d}$ was indicative of a progressive, chronic insult that resulted in nonreversible cell injury and, ultimately, cell death (Cotrans et al. 1989).

Megalocytosis and nuclear pleomorphism with intranuclear pseudoinclusions were prominent features in the livers of fish from the initial submission and fish sampled at 12 and $50 \mathrm{~d}$. Megalocytosis, a consequence of inhibited mitosis, results in polyploid hepatocytes with nuclear pleomorphism or multinucleated hepatocytes. When accompanied by severe or diffuse hepatic necrosis (Kelley 1985), these changes may be especially prominent. Megalocytic diameter exceeded earlier dimensions reported in other teleosts (Myers et al. 1987) and persisted, although uncommon, until the study was terminated at 300 d. A similar condition, megalocytic hepatosis, has been considered a manifestation of chronic toxicity due to sediment contamination and is the most frequently encountered idiopathic lesion in livers of English sole Parophrys vetulis from contaminated sites within Puget Sound, Washington, USA (Myers et al. 1990). Also reported in net-pen cultures of Atlantic salmon Salmo salar in Puget Sound (Kent et al. 1988), megalocytosis has been produced in rainbow trout Oncorhynchus mykiss by exposure to pyrrolizidine alkaloids (Hendricks et al. 1981) and in medaka by exposure to diethylnitrosamine (Hinton et al. $1988 \mathrm{a}, \mathrm{b})$

The intranuclear pseudoinclusions in striped bass of this study were morphologically similar to those observed in livers of senile mouse and human (Andrew et al. 1943, Schauer \& Kunze 1976), rat (Schauer \& Kunze 1976) and mouse hepatocellular carcinomas, mouse livers following chemical insult (Leduc \& Wilson $1959 \mathrm{a}, \mathrm{b})$ and in mouse livers following partial hepatec- tomy (Hollander \& Thung 1966). Electron microscopic studies by Kleinfeld et al. (1956) confirmed that these inclusions represented cytoplasmic invaginations into the nucleus. Cytoplasmic organelles were identified within the inclusions and the nuclear envelope was often found to be continuous with the inclusion body membrane. Herbst (1976) speculated that the cytoplasmic invaginations may occur as a result of reduced intranuclear pressure secondary to nuclear atony possibly due to cellular metabolic alterations, although the pathogenesis of inclusion formation is unknown. Intranuclear pseudoinclusions were present in megalocytic and occasional normal hepatocytes of striped bass until the termination of the study at $300 \mathrm{~d}$ post-submission

Intracytoplasmic inclusions (Fig. 1E) occurred in fish from the initial submission but were most prominent in fish sampled at 12 and $50 \mathrm{~d}$. Similar inclusions have been reported in normal mouse hepatocytes or, more frequently, in well-differentiated mouse hepatocellular tumors within the cisternae of the rough endoplasmic reticulum (Toth et al. 1975). These inclusions are thought to be due to protein accumulation within dilated cisternae secondary to obstruction between the rough endoplasmic reticulum and the Golgi apparatus (Siekevitz \& Palade 1958, Jamieson \& Palade 1971 , Tardini et al. 1971).

The role(s) of individual cell types in repair and regeneration of teleost liver lesions has not been elucidated. In certain fishes, including striped bass, exocrine pancreatic acini exist within the liver proper (Hinton et al. 1984). This has led to the use of the term 'hepatopancreas' to describe this organ. A single hepatic stem cell may differentiate further into biliary epithelial cells, hepatocytes and exocrine pancreatic cells. The spherical to oval cells located within the hepatic glands between the canaliculi and bile ductules were similar in appearance and location to cells described by Hampton et al. (1988) in rainbow trout. Based on their position they may be considered the teleost equivalent of the mammalian bile preductular cell (Steiner \& Carruthers 1961) and their lack of association with a basal lamina further suggests that they may be the teleost equivalent of the mammalian liver stem cell (Sell 1990). Their functional significance, however, may be more closely related to the mammalian bile ductular cell. Proliferation of mammalian bile ductular cells during the initial stages of hepatocarcinogenesis may result in transitional cells with phenotypic alterations characteristic of oval cells (Rubin 1964, Farber \& Cameron 1980). Studies concerning the origin and fate of oval cells have been equivocal and summarized by Rojkind (1988). They appear to be a pluripotent, phenotypically heterogenous, stem cell population of bile ductular origin that 
have been proposed as the progenitor cell type responsible for hepatic regeneration and bile duct proliferation. Phenotypic alteration of oval cells to transitional cells with features of bile ductular cells and hepatocytes (Hayner et al. 1984, Yaswen et al. 1984) and to hepatocytes (Sell \& Leffert 1982) has provided evidence for the pluripotential nature of these cells. Furthermore, stable differentiation has been shown to occur in various mammalian entoderm-derived cell types. Pancreatic acinar cells (Scarpelli \& Rao 1981, Reddy et al. 1984) and pancreatic ductular epithelial cells (Makino et al. 1990) have the potential to convert to hepatocytes. Likewise, pancreatic acinar cells have been shown to occur in rodent liver following chronic exposure to chlorinated biphenyl (Kimbrough 1973). Lee et al. (1989) reported development of exocrine pancreatic cells within trout hepatic neoplasms. Proliferation of spherical to oval cells in these striped bass occurred within hepatic glands in a centrotubular location within cystic parenchymal spaces formed by prior necrosis. The presence and location of these proliferative foci suggested that these 'oval' cells may have been derived from bile preductular cells that have a progenitor function capable of stable differentiation into pancreatic acinar cells or hepatocytes. The occurrence of pancreatic metaplasia adjacent to preexisting intrahepatic pancreatic acinar tissue suggested that the metaplastic cells may have been derived from progenitor cells associated with pancreatic acinar tissue and not from bile preductular cells. The normal occurrence of intrahepatic pancreatic acinar tissue in striped bass obscured the identification and tissue association of the progenitor cell type involved in the pancreatic metaplasia. However, a single progenitor cell in striped bass liver with the potential for differentiation into hepatocytes, biliary epithelial cells and exocrine pancreatic cells is possible.

Hepatic regeneration with complete restoration of architecture in fish sampled at $165 \mathrm{~d}$ indicated that the stroma including the vasculature and biliary system was preserved during the toxic insult (Kelley 1985). Infiltration of inflammatory cells was also a prominent feature in fish from the initial submission and fish sampled at 12 and $50 \mathrm{~d}$. However, there was resolution of inflammation in subsequent samples with no evidence of residual fibrosis. The inflammation was considered to be due to the hepatic necrosis that resolved upon removal of the stimulus, i.e. the hepatotoxin. The bile duct proliferation observed in fish sampled at 12 and $50 \mathrm{~d}$ was also absent in subsequent samples.

Although liver lesions were consistent with an hepatotoxic insult, the etiologic agent was not determined. Hepatic necrosis with megalocytosis and nuclear pleomorphism has been induced in rainbow trout fed diets that contained aflatoxin (Wales 1967). Afla- toxin exposure has also been associated with a high incidence of hepatic neoplasia in fish that survived the initial hepatic insult (Ashley 1967 Simon et al. 1967. Wales 1967, Sinnhuber et al. 1977. Wales et al. 1978). Although there was no evidence of neoplastic or preneoplastic lesions in the livers of these striped bass during the course of the study, the similarity of lesions suggested that aflatoxins were a possible etiological agent. However, the fish were not fed a commercial diet which is the usual route of exposure for aflatoxininduced hepatotoxicity.

Syncytial cell formation due to hepatocellular fusion and loss of adjacent plasmalemma was observed in fish from the initial submission and at $12 \mathrm{~d}$. Similar lesions have been produced in cats experimentally exposed to dioxin (Kelley 1985). Megalocytosis has also been induced in fish following exposure to other xenobiotic agents including polychlorinated biphenyls (Hinton et al. 1978), endrin (Eller 1971) and nitrosamines (Stanton 1965, Ashley \& Halver 1968) and has been observed in wild fish from polluted environments (Myers et al. 1987, Peters et al. 1987). The term megalocytosis was initially used to describe the nuclear and cytoplasmic changes that occur in pyrollizidine alkaloid toxicity (Kelley 1985). The pyrollizidine alkaloids are natural components of several botanical families that have an antimitotic effect but do not inhibit DNA synthesis resulting in nuclear enlargement and cytomegaly (McLean 1970, Mattocks 1986). Pyrollizidine alkaloids were considered the possible hepatotoxin due to the similarity of lesions in these striped bass with those in domestic animals (McLean 1970, Kelley 1985, Mattocks 1986) and rainbow trout (Hendricks et al. 1981) and the history of discarding vegetation into the ponds prior to the onset of mortality. Alkaloid-containing plants are indigenous to California (Fuller \& McClintock 1986) although there is no evidence that this would lead to aqueous exposure. Also, cow manure, used to fertilize the affected pond, may have contained pyrollizidine alkaloids or their metabolites. However, laboratory exposure to pyrollizidine alkaloids failed to produce hepatic lesions including megalocytosis previously observed in net-pen reared Atlantic salmon in British Columbia, Canada (Kent 1990).

Exposure of striped bass to abundant algal blooms also implicated algal phytotoxins as a possible cause of the liver lesions. Acute hepatic necrosis in mammals has been associated with exposure to algal phytotoxins (Kelley 1985). Hepatic lesions have also been described in Atlantic salmon exposed to Chattonella-like algal blooms although megalocytosis was not a feature of the disease (Tett 1980).

Although there are 13 extrahepatic sites for P450 enzymes, the teleost liver is the major locus for this important system and may function to bioactivate as 
well as detoxify potential toxicants (Stegeman et al. 1979). There is limited information on striped bass specific metabolism compared with other teleost fishes including the rainbow trout, scup Stenotomus chrysops, winter flounder and English sole. However, based on studies in these species, a similar enzyme system may be present in the liver of striped bass and may have been involved in activation of the suspected toxicant in these striped bass. The apparent induction of endoplasmic reticulum proliferation suggested prior exposure (Klaunig et al. 1979, Schoor \& Couch 1979). The vast majority of aquatic toxicity studies with early life stages of striped bass have been restricted to acute exposure and have not included metabolic studies and/ or histopathologic examination (Hall 1991).

In conclusion, these observations indicate that the striped bass liver is sensitive to potential toxicants but is capable of repair and regeneration following sublethal injury. Furthermore, a pluripotent stem cell capable of differentiation into 3 epithelial cell types may be essential for hepatic repair and regeneration in these vertebrates. Further laboratory studies are presently in progress in our laboratory to elucidate mechanisms of pathogenesis and to evaluate various hepatotoxins in striped bass.

Acknowledgements. The authors thank Drs Michael L. Kent and Mark S. Okihiro for their helpful suggestions, Mr Robert Munn for his electron microscopy expertise, the histotechnicians of the Veterinary Medical Teaching Hospital for the processing of tissue samples and Mrs Vicki Martin for typing the manuscript.

\section{LITERATURE CITED}

Amos, K. H. (1985). Procedures for detection and identification of certain pathogens, 3rd edn. Fish Health Section, American Fisheries Society, Corvallis

Andrew, W., Brown, H. M., Johnson, J. B. (1943). Senile changes in the liver of mouse and man, with special reference to the similarity of nuclear alterations. Am. J. Anat. 72: 199-221

Ashley, L. M. (1967). Histopathology of rainbow trout aflatoxicosis. In: Halver, J. E., Mitchell, I. A. (eds.) Trout Hepatoma Research Conference papers. Research Report 70, Bureau of Sport Fisheries and Wildlife, Washington, DC

Ashley, L. M., Halver, J, E. (1968). Dimethylnitrosamineinduced hepatic cell carcinoma in rainbow trout. $J$. nat. Cancer Inst. 41: 531-552

Bodammer, J. E.. Murchelano, R. A. (1990). Cytological study of vacuolated cells and other aberrant hepatocytes in winter flounder from Boston Harbor. Cancer Res. 50: 6744-6756

Braunbeck, T A, Teh, S., Lester, S. M., Hinton, D. E. (in press). Ultrastructural alterations in hepatocytes of medaka (Oryzias latipes) exposed to diethylnistrosamine. Toxicol. Path.

Brown, C. L., Young, G., Nishioka, R. S., Bern, H. A. (1987). Preliminary report on the physiological status of striped bass in the Carquinez Strait die-off. Fish. Res. 6: 5-16
Cotrans, R. S., Kumar, V., Robbins, S. L. (1989). Pathologic basis of disease, 4 th edn. W. B. Saunders Co. Philadelphia

Eldridge, M. B., Whipple, J. A., Eng, D., Bowers, M. J., Jarvis, B. M. (1981). Effects of food and feeding factors on laboratory-reared striped bass larvae. Trans. Am. Fish. Soc. 110 $111-120$

Eller, L. L. (1971). Histopathological lesions in cutthroat trout (Salmo clarki) exposed chronically to the pesticide endrin. Am. J. Path. 64: 321-336

Farber, E., Cameron, R. G. (1980). The sequential analysis of cancer development. Adv. Cancer Res. 31:125-226

Fuller, T. C., McClintock, E. (1986). Poisonous plants of California. University of California Press, Berkeley

Gardner, G. R., Pruell, R. J., Folmar, L. C. (1989). A comparison of both neoplastic and non-neoplastic disorders in winter flounder (Pseudopleuronectes americanus) from eight areas in New England. Mar environ. Res. 28. 393-397

Groman, D. B. (1982). Histology of the striped bass. Am. Fish. Monogr. 3, American Fisheries Society, Bethesda

Hall, L. W. Jr. (1991). A synthesis of water quality and contaminants data on early life stages of striped bass, Morone saxatilis. Rev. aquat. Sci. 4(2-3). 261-288

Hampton, J. A., Lantz, R. C., Goldblatt, P. J., Laurén, D. J., Hinton, D. E. (1988). Functional units in rainbow trout (Salmo gairdneri, Richardson) liver: II. The biliary system. Anat. Rec. 221: 619-634

Hampton, J. A., McCuskey, P. A., McCuskey, R. S., Hinton, D. E. (1985). Functional units in rainbow trout (Salmo gairdneri, Richardson) liver I. Histochemical properties and arrangement of hepatocytes. Anat. Rec. 213: 166-175

Hardy, J. D. Jr (1978). Development of fishes of the MidAtlantic Bight: an atlas of the egg, larval, and juvenile stages, Vol. III, Aphredoderidae through Rachycentridae. U.S. Fish Wildl. Serv. Biol. Serv. Prog. FWS/OBS-78/12, Fort Collins

Harshbarger, J. C., Clark, J. B. (1990). Epizootiology of neoplasms in bony fish of North America. Sci. Total Environ. 94: $1-32$

Hayner, N. T., Braun, L., Yaswen, P., Brooks, M., Fausto, N (1984). Isozyme protiles of oval cells, parenchymal cells and biliary cells isolated by centrifuged elutriation from normal and neoplastic livers. Cancer Res. 44: 332-338

Hendricks, J. D., Sinnhuber, R. O., Henderson, M. C., Buhler, D. R. (1981). Liver and kidney pathology in rainbow trout (Salmo gairdneri) exposed to dietary pyrrolizidine (Senecio) alkaloids. Exp. molec. Pathol. 35:170-183

Herbst, M. (1976). Glycogenous hepatonuclear inclusions in the aged mouse - an electron microscopic study of the histogenesis of nuclear inclusions. Pathol. Eur 11:69-79

Hinton, D. E. (1990). Histological techniques. In: Schreck, C. B., Moyle, P. B. (eds.) Methods for Fish Biology. American Fisheries Society Special Publications Series, Bethesda, p. 191-211

Hinton. D. E., Baumann, P. C., Gardner, G. R., Hawkins, W. E., Hendncks, J. D., Murchelano, R. A., Okihiro, M. S. (1992). Histopathological biomarkers. In: Huggett, R. J., Kimerle, R. A., Mehrle, P. M., Bergman, H. L. (eds.) Biomarkers: biochemical, physiological, and histological markers of anthropogenic stress. Lewis Publishers, Boca Raton, p. $155-209$

Hinton, D. E., Couch, J. A., Teh, S. J., Courtney, L. A. (1988a). Cytological changes during progression of neoplasia in selected fish species. Aquat. Toxicol. 11 77-112

Hinton, D. E., Klaunig, J. E., Lupsky, M. M. (1978). PCBinduced alterations in teleost liver a model for environmental disease in fish. Mar. Fish. Rev. 40: 47-50 
Hinton, D. E., Laurén, D. J., Teh, S. J., Giam, C. S. (1988b) Cellular composition and ultrastructure of hepatic neoplasms induced by diethylnitrosamine in Oryzias latipes. Mar environ. Res. 24: 307-310

Hinton, D. E., Pool, C. R. (1976). Ultrastructure of the liver in channel catfish Ictalurus punctatus (Rafinesque). J. Fish Biol. 8: 209-219

Hinton, D. E., Walker, E. R., Pinkstaff, C. A., Zuchelkowski, E. M. (1984). Morphological survey of teleost organs important in carcinogenesis with attention to fixation. Natn. Cancer Inst. Monogr. 65: 291-320

Hollander, C. F., Thung, P. J. (1966). Relations between regenerative growth and ageing in the mouse liver. In: Lindop, P. J., Sacher, G. A. (eds.) Proc. colloquium on radiation and ageing. Taylor and Francis, London, p. 3-14

Humason, G. L. (1979). Animal tissue techniques. W. H. Freeman, San Francisco

Jamieson, J. D., Palade, G. E. (1971). Synthesis, intracellular transport, and discharge of secretory protein in stimulated pancreatic exocrine cells. J. Cell Biol. 50: 135-138

Kelley, W. R. (1985). The liver and biliary system. In: Jubb, K. V F., Kennedy, P. C., Palmer, N. (eds.) Pathology of domestic animals, Vol. II, 3rd edn. Academic Press, Orlando, p. 239-312

Kent, M. L. (1990). Net pen liver disease (NLD) of salmonid fishes reared in seawater: species susceptibility, recovery and probable cause. Dis. aquat. Org. 8: 21-28

Kent, M. L., Myers, M. S., Hinton, D. E., Eaton, W. D., Elston, R. A. (1988). Suspected toxicopathic hepatic necrosis and megalocytosis in pen-reared Atlantic Salmon Salmo salar in Puget Sound, Washington, USA. Dis. aquat. Org. 4: 91-100

Kimbrough, R. D. (1973). Pancreatic-type tissue in livers of rats fed polychlorinated biphenyls. J. natn. Cancer Inst. 51: 679-680

Klaunig, J. E., Lipsky, M. M., Trump, B. F., Hinton, D. E (1979). Biochemical and ultrastructural changes in teleost liver following subacute exposure to PCB. J. environ. Path. Toxicol. 2: 953-963

Kleinfeld, R. G., Greider, M. H., Frajola, W. J. (1956). Electron microscopy of intranuclear inclusions found in human and rat liver parenchymal cells. J. biophys. biochem. Cytol. 2 (suppl.): $435-438$

Laurén, D. J., Teh, S. J., Hinton, D. E. (1990). Cytotoxicity phase of diethylnitrosamine-induced hepatic neoplasia in medaka. Cancer Res. 50: 5504-5514

Leduc, E. H., Wilson, J. W. (1959a). A histochemical study of intranuclear inclusions in mouse liver and hepatoma. $J$. Histochem. Cytochem. 7: 8-16

Leduc, E. H., Wilson, J. W. (1959b). An electron microscope study of intranuclear inclusions in mouse liver and hepatoma. J. biophys. biochem. Cytol. 6: 427-430

Lee, B. C., Hendricks, J. D., Bailey, G. S. (1989). Metaplastic pancreatic cells in liver tumors induced by diethylnitrosamine. Exp. molec. Pathol. 50: 104-113

Luna, L. G. (1968). Armed Forces Institute of Pathology manual of histological staining, McGraw Hill, New York

Makino, T., Usuda, N., Rao, S., Reddy, J. K., Scarpelli, D. G (1990). Transdifferentiation of ductular cells into hepatocytes in regenerating hamster pancreas. Lab. Invest. 62(5) $552-561$

Mattocks, A. R. (1986). Chemistry and toxicology of pyrollizidine alkaloids. Academic Press, Montreal

McLean, E. K. (1970). The toxic actions of pyrollizidine (Senecio) alkaloids. Pharmac. Rev. 22: 429-483

Meyers, T. R., Hendricks, J. D. (1985). Histopathology. In: Rand, G. M., Petrocelli, S. R. (eds.) Fundamentals of aquatic toxicology. Hemisphere Publishing, Washington, DC
Moore, M. J., Smolowitz, R., Stegeman, J. J. (1989). Cellular alterations preceding neoplasia in Pseudopleuronectes americanus from Boston Harbor. Mar. environ. Res. 28: $425-429$

Murchelano, R. A., Wolke, R. E. (1985). Epizootic carcinoma in the winter flounder Pseudopleuronectes americanus. Science 228: $587-589$

Myers, M. S., Landahl, J. T., Krahn, M. M., Johnson, L. L., McCain, B. B. (1990). Overview of studies on liver carcinogenesis in English sole from Puget Sound; evidence for a xenobiotic chemical etiology pathology and epizootiology. Sci. Total Environ. 94: 33-50

Myers, M. S., Rhodes, L. D., McCain, B. B. (1987). Pathologic anatomy and patterns of occurrence of hepatic neoplasms, putative preneoplastic lesions, and other idiopathic hepatic conditions in English sole (Parophrys vetulus) from Puget Sound, Washington. J. natn. Cancer Inst. 78 : 333-363

Peters, N., Köhler, A., Kranz, H. (1987). Liver pathology in fishes from the Lower Elbe as a consequence of pollution. Dis. aquat. Org. 2: 87-97

Plaa, G. L. (1986). Toxic responses of the liver. In: Klaassen, C. D., Amdur, M. O., Doull, J. (eds.) Toxicology: the basic science of poisons, 3rd edn. Macmillan Publishing Co., New York, p. 286-309

Popper, H. (1988). Hepatocellular degeneration and death. In Arias, I. M., Jakoby, W. B., Popper, H., Schacter, D., Shafritz, D. A. (eds.) The liver: biology and pathobiology, 2nd edn., Raven Press, New York, p. 1087-1103

Reddy, J. K., Rao, M. S., Qureshi, S. A., Reddy, M. K., Scarpelli, D. G., Lalwoni, N. D. (1984). Induction and origin of hepatocytes in rat pancreas. J. Cell Biol. 98: 2082-2090

Rojkind, M. (1988). Extracellular matrix. In: Arias, I. M. Jakoby, W. B., Popper, H., Schacter, D., Shafritz, D. A (eds.) The liver: biology and pathobiology, 2nd edn. Raven Press, New York, p. 707-737

Rubin, E. (1964). The origin and fate of proliferative bile ductular cells. Exp. molec. Path. 3: 279-286

Scarpelli, D. G., Rao, M. S. (1981). Differentiation of regenerating pancreatic cells into hepatocyte-like cells Proc. natl Acad. Sci. USA 78: 2577-2581

Schauer, A., Kunze, E. (1976). Tumors of the liver. In: Turusov, V S. (eds.) Pathology of tumors in laboratory animals, Vol 1: Tumors of the rat, Part 2. IARC Sci. Pub. No. 6, Lyon, p $41-72$

Schoor, W. P., Couch, J. A. (1979). Correlations of mixed-function oxidase activity with ultrastructural changes in the liver of a marine fish. Cancer Biochem. Biophys. 4: 95-103

Sell, S. (1990). Is there a liver stem cell? Cancer Res. 50: $3811-3815$

Sell, S., Leffert, H. (1982). An evaluation of cellular lineages in the pathogenesis of experimental hepatocellular carcinoma. Hepatol. 2: 77-86

Siekevitz, P., Palade, G. E. (1958). A cytochemical study on the pancreas of the guinea pig. Il. Functional variations in the enzymatic activity of microsomes. J biophys biochem. Cytol. 4 : 309-318

Simon, R. C., Dollar, A. M., Smuckler, E. A. (1967). Descriptive classification of normal and altered histology of trout livers. In: Halver, J. E., Mitchell, I. A. (eds.) Trout Hepatoma Research Conference papers. Research Report \#70, U.S. Fish and Wildlife Service, Washington, DC, p. $18-28$

Sinnhuber, R. O., Hendricks, J. D., Wales, J. H., Putnam, G. B. (1977). Neoplasms in rainbow trout, a sensitive animal model for environmental carcinogenesis. Ann. N.Y. Acad. Sci. 298: 389-408 
Stanton, M. F. (1965). Diethylnitrosamine-induced hepatic degeneration and neoplasia in the aquarium fish, Brachydanio rerio. J. natn. Cancer Inst. 34: 117-130

Stegeman, J. J., Binder, R. L., Orren, A. (1979). Hepatic and extrahepatic microsomal electron transport components and mixed-function oxygenases in the marine fish Stenotomus versicolor. Biochem. Pharmac. 28: $3431-3429$

Steiner, J. W., Carruthers, J. S. (1961). Studies on the fine structure of the terminal branches of the biliary tree. Am. J. Path. 38: 639-661

Stevens, D. E., Kohlhorst, D. W., Miller, L. W. (1985). The decline of striped bass in the Sacramento-San Joaquin Estuary, California. Trans. Am. Fish. Soc. 114: 12-30

Tardini, A., Anversa, P., Bordi, C., Bertaccini, G., Impicciatore, M. (1971). Ultrastructural and biochemical changes after marked caerulein stimulation of the exocrine pancreas in the dog. Am. J. Path. 63: 35-56

Responsible Subject Editor: O. Kinne, Oldendorf/Luhe, Germany
Tett, P. (1980). Phytoplankton and the fish kills in Loch Striven. Scottish Mar. Biol. Ass. Internal Rep. No. 25, Oban

Toth, K., Somosy, Z., Bence, J., Sugar, J. (1975). Study of globular bodies found in hepatoma of Swiss mice. $Z$. Krebsforsch. 94: 67-73

Wales, J. H. (1967). Degeneration and regeneration of liver parenchyma accompanying hepatomagenesis. Trout Hepatoma Research Conference papers. Research Report \# 70, Bureau of Sport. Fisheries and Wildlife, Washington, DC, p. $56-59$

Wales, J. H., Sinnhuber, R. O., Hendricks, J. D., Nixon, J. E. Eisele, T. A. (1978). Aflatoxin $\mathrm{B}_{1}$ induction of hepatocellular carcinoma in the embryos of rainbow trout (Salmo gairdneri). J. natn. Cancer Inst. 60: 1133-1139

Yaswen, P., Hayner, N. T., Fausto, N. (1984). Isolation of oval cells by centrifugal elutriation and comparison with other cell types purified from normal and neoplastic livers Cancer Res. 44: 324-331

Manuscript first received: April 28, 1992 Revised version accepted: June 29, 1992 